\title{
Glycosyltransferase Activities of Ehrlich Ascites Tumor Cells: Detection, Isolation, and Characterization Using Oligosaccharide-Synsorb Beads ${ }^{1}$
}

\author{
MARIANO J. ELICES ${ }^{2}$ AND IRWIN J. GOLDSTEIN ${ }^{3}$ \\ Depurtment of Biological Chemistry, University of Michigan, Ann Arbor, Michigan 48109
}

Received October 20, 1986, and in revised form December 1, 1986

Detergent extracts of Ehrlich tumor cell membranes exhibit a host of glycosyltransferase activities which have been investigated using oligosaccharides immobilized to Synsorb beads as acceptors. Glycosidase digestions in combination with methylation analysis of the insoluble products have demonstrated the presence of an $\alpha(1,3)$-galactosyltransferase and a $\beta(1,3)-N$-acetylglucosaminyltransferase, enzymes that utilize $N$ acetyllactosamine as their acceptor substrate. The two enzymes are presumably involved in the biosynthesis of $\alpha$-D-galactosyl-terminated poly- $N$-acetyllactosamine glycans that occur on the surface of Ehrlich cells. In addition, a $\beta$-galactosyltransferase acting on $N$-acetylglucosamine and a separate $\beta$ - $N$-acetylglucosaminyltransferase that is capable of incorporating GlcNAc into the trisaccharide $\beta-\mathrm{D}-\mathrm{GlcNAc}(1,3)-\beta-\mathrm{D}-\mathrm{Gal}(1,4)-\beta-\mathrm{D}-\mathrm{Glc}-$ Synsorb have been identified. The Ehrlich cell $\alpha$ - and $\beta$-galactosyltransferases have been separated by chromatography on $\beta$-GlcNAc-Synsorb beads. In the presence of $\mathrm{MnCl}_{2}$ and UDP the $\beta$-galactosyltransferase is specifically adsorbed to the monosaccharide column whereas the $\alpha$-galactosyltransferase passes through unretarded. $\odot 1987$ Academic Press, Inc.

Glycosyltransferases comprise a family of enzymes that catalyze the incorporation of a specific monosaccharide (donor moiety) in glycosidic linkage to an acceptor molecule (1). The enzymatic reaction results in the synthesis of oligosaccharides, polysaccharides, glycoproteins, glycolipids, or glycosaminoglycans, depending on the nature of the acceptor substrate. Even when macromolecular acceptors are involved, only a minimal carbohydrate structure is generally required for recognition by the transferase. The donor substrate consists of the monosaccharide bound to a specific carrier, which in most instances is a nucleotide, e.g.,

\footnotetext{
${ }^{1}$ This work was supported by National Institutes of Health Grant CA 20424.

${ }^{2}$ Recipient of a Rackham Predoctoral Fellowship.

${ }^{3}$ To whom correspondence should be addressed at Department of Biological Chemistry, University of Michigan, 4320 Medical Science 1, Ann Arbor, MI 48109-0606.
}

UDP for glucose and galactose, GDP for mannose and fucose, and CMP for sialic acid. All glycosyltransferases studied thus far appear to be consistent with the concept that each glycosidic linkage is synthesized by a separate enzyme (2).

Because glycosyltransferases are present in very small amounts in tissues and are often tightly bound to membranes, detection and purification pose a difficult task. Several methods have been devised to assay for transferase activities. The procedure most commonly used measures the incorporation of radioactive monosaccharide from a nucleotide-sugar donor into the appropriate acceptor substrate, typically a soluble substance. This assay was first employed to determine lactose synthase activity in preparations of guinea pig and bovine mammary glands (3).

A major development in the purification of glycosyltransferases occurred when Barker et al. (4) employed an affinity ad- 
sorbent containing UDP-hexanolamine to obtain high yields of a homogeneous preparation of $\beta$-galactosyltransferase from bovine milk. Subsequently, a variety of glycosyltransferases have been successfully isolated by exploiting the specificity of their nucleotide binding site (5).

In the present study we describe the use of a solid-phase system which utilizes oligosaccharide-derivatized Synsorb beads as a general procedure for the assay of glycosyltransferases. The insoluble products resulting from the transferase reaction may be analyzed further by conventional enzymatic and chemical procedures such as glycosidase digestion and methylation analysis. Furthermore, $\beta$-GlcNAc $c^{4}-\mathrm{Syn}$ sorb beads have been employed in the purification of $\beta$-galactosyltransferase from Ehrlich ascites tumor cells. A preliminary report of this work has been presented (6).

\section{EXPERIMENTAL PROCEDURES}

Materials. Synsorb beads containing covalently bound oligosaccharides (degree of substitution, $1 \mathrm{nmol}$ oligosaccharide/mg of beads) were the generous gift of Drs. D. A. Baker and R. M. Ratcliffe (Chembiomed, Ltd., Alberta, Canada). UDP-[U $\left.{ }^{14} \mathrm{C}\right] \mathrm{Gal}(337 \mathrm{mCi} /$ mmol), UDP-[U- $\left.{ }^{14} \mathrm{C}\right] \mathrm{GlcNAc}(297 \mathrm{mCi} / \mathrm{mmol})$, and $\mathrm{D}^{-}$ [U-14 $\mathrm{C}] \mathrm{Gal}(52.9 \mathrm{mCi} / \mathrm{mmol})$ were obtained from DuPont/New England Nuclear. CMP-[U-14 $\mathrm{C}]$ NeuNAc $(1.8 \mathrm{mCi} / \mathrm{mmol})$ and GDP-[U- $\left.{ }^{14} \mathrm{C}\right] \mathrm{Fuc}(0.7 \mathrm{mCi} / \mathrm{mmol})$ were kindly donated by Dr. A. E. Eckhardt, Duke University. $N$-Acetyllactosamine and $N-\left[6^{\prime}{ }^{8} \mathrm{H}-\mathrm{D}-\right.$ Gal]acetyllactosamine were synthesized by Nike $R$. Plessas in this laboratory (7). Bovine milk galactosyltransferase, $\alpha$-lactalbumin, Triton X-100, UMP, UDP, and unlabeled UDP-Gal and UDP-GlcNAc were obtained from Sigma. Bovine serum albumin (Pentex Fraction V) was a product of Miles Laboratories. Coffee bean $\alpha$-galactosidase (EC 3.2.1.22) and beef kidney $\beta$ - $N$-acetylglucosaminidase (EC 3.2.1.30) were purchased from Boehringer Mannheim. Escherichia coli

\footnotetext{
${ }^{4}$ Abbreviations used: GlcNAc, $N$-acetyl-D-glucosamine; Gal, D-galactose; Fuc, L-fucose; NeuNAc, $N$ acetylneuraminic acid; LacNAc, $N$-acetyllactosamine; Hepes, 4-(2-hydroxyethyl-1-piperazineethanesulfonic acid; Mes, 2-( $N$-morpholino)-ethanesulfonic acid; PMSF, phenylmethylsulfonyl fuoride; BSA, bovine serum albumin; DMSO, dimethylsulfonyl oxide; SDS, sodium dodecyl sulfate; PAGE, polyacrylamide gel electrophoresis.
}

$\beta$-galactosidase (EC 3.2.1.23) was from Sigma, and Aspergillus $\beta$-galactosidase was from Calbiochem. Bovine testicular $\beta$-galactosidase was prepared according to the method of Distler and Jourdian (8). The No. 3MM paper was obtained from Whatman and the SS 589 blue ribbon paper was from Schleicher and Schuell. Solvents and chemicals employed in the methylation and chromatographic procedures were of the highest purity available. Partially methylated galactose standards were prepared by Nike R. Plessas in this laboratory.

Preparation of Ehrlich cell extracts. Ehrlich ascites tumor cells were passaged by intraperitoneal injection of male Swiss white mice and harvested 7-10 days after transfer. The ascites fluid was filtered through cheesecloth into an ice-cold saline solution $(0.15 \mathrm{M}$ $\mathrm{NaCl}$ ). All procedures thereafter were performed at $4^{\circ} \mathrm{C}$. Ehrlich cells were centrifuged at $900 \mathrm{~g}$ for $1 \mathrm{~min}$ and washed repeatedly in the above saline solution to remove red blood cells. This step was followed by two washes with homogenization buffer ( $15 \mathrm{mM}$ Tris- $\mathrm{HCl}$, $\mathrm{pH} 7.5,15 \mathrm{mM} \mathrm{NaCl}$, and $1 \mathrm{mM} \mathrm{MgCl} 2$ ) and centrifugation at $2000 \mathrm{~g}$ for $2 \mathrm{~min}$. Ehrlich cells were suspended in an equal volume of homogenization buffer and kept on ice for $20 \mathrm{~min}$, and the swollen cells were homogenized in a glass Dounce apparatus fitted with a tight pestle. Complete cellular disruption was monitored by light mirrnseopy. The Ehrlich cell homogenate was centrifuged at $650 \mathrm{~g}$ for $10 \mathrm{~min}$ to remove unbroken cells and nuclei (9). The postnuclear fraction was centrifuged at $100,000 \mathrm{~g}$ for $60 \mathrm{~min}$ and the pellet. was extracted with $20 \mathrm{mM}$ Hepes buffer, $\mathrm{pH} 7.0,0.4 \%$ (v/ v) Lubrol PX, $2 \mathrm{mM} \beta$-mercaptoethanol, $1 \mathrm{mM}$ PMSF, and $25 \%$ glycerol, with stirring overnight. The detergent extract was clarified by centrifugation at $100,000 \mathrm{~g}$ for $1 \mathrm{~h}$, and the supernatant solution was used for transferase assays.

Preparation of beads. Stock suspensions of oligosaccharide-Synsorb beads $(20 \mathrm{mg}$ of beads $/ \mathrm{ml})$ were prepared in distilled water containing $0.04 \%$ sodium azide. For glycosyltransferase assays, $0.25-\mathrm{ml}$ aliquots ( $5 \mathrm{mg}$ of beads) were removed and the beads were washed twice with $1 \mathrm{ml} \mathrm{H}_{2} \mathrm{O}$ prior to use.

Preparation of ${ }^{{ }^{4}} \mathrm{C}$-labeled $\mathrm{N}$-acetyllactosamineSynsorb. $\beta$-GlcNAc-Synsorb beads $(20 \mathrm{mg})$ were incubated in a total volume of $0.2 \mathrm{ml}$ containing the following components: $50 \mathrm{mM}$ cacodylate buffer, $\mathrm{pH}$ 7.4, $25 \mathrm{mM} \mathrm{MnCl} 2,2 \mathrm{mM} \beta$-mercaptoethanol, $1 \mathrm{mg} / \mathrm{ml}$ $\mathrm{BSA}$, and $0.31 \mathrm{mM}$ UDP- $-\left[{ }^{14} \mathrm{C}\right] \mathrm{Gal}(0.1 \mu \mathrm{Ci})$. After equilibrating the suspension at $37^{\circ} \mathrm{C}, 1.0 \mathrm{mU}$ of bovine milk galactosyltransferase was added ( $1 \mathrm{U}$ transfers $1 \mu \mathrm{mol}$ of $\mathrm{D}$-Gal per minute), the tubes were mixed vigorously for $15 \mathrm{~s}$, and the beads were allowed to settle. Incubations were carried out at $37^{\circ} \mathrm{C}$ for $4 \mathrm{~h}$, after which a further amount of transferase was added $(1.0 \mathrm{mIJ})$, and reactions were continued for an additional $4 \mathrm{~h}$. Incubations were stopped by adding $1 \mathrm{ml}$ of $0.1 \mathrm{M}$ FDTA, and the beads were centrifuged followed by 
aspiration of the supernatant solution and washed with $\mathrm{H}_{2} \mathrm{O}$ ( $1 \mathrm{ml}$, four times). Finally, the beads were resuspended in $2 \mathrm{ml}$ of $\mathrm{H}_{2} \mathrm{O}$ and $0.1-\mathrm{ml}$ aliquots were taken for scintillation counting.

Methylation of oligosaccharide-substituted beads. $\left[{ }^{14} \mathrm{C}\right] \mathrm{Gal}-N$-acetyllactosamine-Synsorb beads which had been subjected to the action of glycosyltransferase ( $5 \mathrm{mg}$ beads, $8000 \mathrm{cpm}$ ) were transferred to Teflonlined screw-cap hydrolysis tubes, washed twice with $1 \mathrm{ml}$ of $\mathrm{H}_{2} \mathrm{O}$, and dried in vacuo overnight. The dried beads were suspended in $0.5 \mathrm{ml}$ of anhydrous DMSO and $0.5 \mathrm{ml}$ of freshly prepared $2 \mathrm{M}$ sodium dimethylsulfinylmethanide was added (10). Tubes were flushed with nitrogen and tightly capped. Continuous suspension of the beads was achieved by agitating the tubes in an ultrasonic bath at room temperature for a combined time of $1 \mathrm{~h}$ divided into six bursts of $10 \mathrm{~min}$ each, with cooling to ambient temperatures between each interval. An additional amount of $2 \mathrm{M}$ sodium dimethylsulfinylmethanide was added $(0.3 \mathrm{ml})$, and suspensions were agitated for $1 \mathrm{~h}$ and cooled in an ice-water bath. Methyl iodide $(1 \mathrm{ml})$ was added dropwise, and the tubes were allowed to warm to room temperature followed by ultrasonic agitation for $1 \mathrm{~h}$. Reaction mixtures were kept at room temperature overnight and excess reagents were removed by centrifuging the beads at $12,000 \mathrm{~g}$ for $5 \mathrm{~min}$ and aspirating the supernatant solution. The beads were washed successively with methanol ( $1 \mathrm{ml}$, four times) and $\mathrm{H}_{2} \mathrm{O}$ ( $1 \mathrm{ml}$, four times). Hydrolysis of the covalently bound permethylated oligosaccharides was accomplished by treating the beads with $1 \mathrm{ml}$ of $4 \mathrm{~N}$ trifluoroacetic acid at $100^{\circ} \mathrm{C}$ for $2-3 \mathrm{~h}$. The beads were then centrifuged and washed three times with $1 \mathrm{ml}$ of $\mathrm{H}_{2} \mathrm{O}$. The first supernatant solution and the $\mathrm{H}_{2} \mathrm{O}$ washes were carefully removed and combined, followed by repeated evaporation until all the acid had been eliminated. The partially methylated $\left[{ }^{14} \mathrm{C}\right] \mathrm{galactose}$ species, recovered in the soluble fraction, were analyzed by thinlayer chromatography on plastic-backed plates of silica gel G (0.25 mm; Brinkmann Instruments). Thinlayer chromatograms were developed at $4^{\circ} \mathrm{C}$, dried, and developed a second time with the solvent system benzene:acetone:water:ammonium hydroxide (50:200: $3: 1.5 ; \mathrm{v} / \mathrm{v} / \mathrm{v} / \mathrm{v})$. Plates were cut into segments $(0.5 \times 1.5$ $\mathrm{cm}$ ) and radioactivity was measured by counting in $0.4 \%(\mathrm{w} / \mathrm{v})$ diphenyloxazole in toluene as the scintillation fluid. 0 -Methylgalactose standards were run separately on the same plates and visualized by spraying with a solution containing $5 \%$ each of ammonium molybdate, phosphoric acid, and sulfuric acid, followed by heating the plates at $140^{\circ} \mathrm{C}$ for $5 \mathrm{~min}$.

Isolation of oligosaccharide products. Incubations containing soluble oligosaccharides as acceptors were spotted on sheets of Whatman No. 3MM paper, divided in $0.5 \times 1.5$-in. segments. Paper electrophoresis was performed in a Gilson Model $D$ electrophorator for $30 \mathrm{~min}$ at $3500 \mathrm{~V}$ with the solvent system $1.24 \mathrm{M} \mathrm{pyr}-$ idine/0.064 M acetic acid, $\mathrm{pH}$ 6.4. Paper strips were cut and radioactivity was measured with $0.4 \%(\mathrm{w} / \mathrm{v})$ diphenyloxazole in toluene as the scintillation fluid.

oligosaccharide products remaining at the origin of the electrophoretogram were eluted from the paper with $\mathrm{H}_{2} \mathrm{O}$, dried, and analyzed by descending paper chromatography on SS 589 blue ribbon paper using the solvent system 1-butanol:pyridine:water $(6: 4: 3, \mathrm{v} / \mathrm{v} / \mathrm{v})$.

Transferase assays. All glycosyltransferase assays were carried out in conical plastic tubes, containing $5 \mathrm{mg}$ of the appropriate oligosaccharide-Synsorb beads (approximately $10 \mu \mathrm{l}$ wet vol) in a total volume of $0.1 \mathrm{ml}$. After addition of the buffered incubation mixture, samples were equilibrated at $37^{\circ} \mathrm{C}$ for $2 \mathrm{~min}$. An aliquot of transferase-containing fractions was added, tubes were capped and mixed vigorously for $15 \mathrm{~s}$, and the beads were allowed to settle. Incubations were initiated by placing the samples in a Temp-blok module heater (Scientific Products) at $37^{\circ} \mathrm{C}$ for $1 \mathrm{~h}$. Reactions were quenched by adding $1 \mathrm{ml}$ of $0.1 \mathrm{M}$ EDTA, the beads were centrifuged on a desk-top centrifuge, the supernatant solution was aspirated, and the beads were washed four times with $1 \mathrm{ml}$ of $\mathrm{H}_{2} \mathrm{O}$. Radioactivity was measured by resuspending the beads in $1 \mathrm{ml}$ of $\mathrm{H}_{2} \mathrm{O}$ and taking $0.2-\mathrm{ml}$ aliquots for scintillation counting in the presence of $5 \mathrm{ml}$ of Safetysolve (Research Products International).

$\alpha$-Galactosyltransferase activity was determined using $N$-acetyllactosamine-Synsorb beads ( $1 \mathrm{nmol}$ disaccharide/mg beads) containing the following components: $20 \mathrm{mM}$ Mes, $\mathrm{pH} 6.1,5 \mathrm{mM} \mathrm{MnCl}_{2}, 0.5 \%$ (v/v) Triton X-100, $2 \mathrm{mM} \beta$-mercaptoethanol, and 0.16 mM UDP- $\left[{ }^{14} \mathrm{C}\right] \mathrm{Gal}(0.1 \mu \mathrm{Ci})$. When partially purified enzyme was assayed, BSA $(1 \mathrm{mg} / \mathrm{ml})$ was also included in the incubation mixtures.

$\beta$-Galactosyltransferase activity was measured using as acceptor $\beta$-GlcNAc-Synsorb beads ( $1 \mathrm{nmol}$ monosaccharide/mg beads) in the presence of the following components: $20 \mathrm{mM}$ Hepes, pH 7.0, $5 \mathrm{mM} \mathrm{MnCl}_{2}$, $0.5 \%(\mathrm{v} / \mathrm{v})$ Triton X-100, $2 \mathrm{mM} \beta$-mercaptoethanol, and $0.23 \mathrm{mM}$ UDP- $\left[{ }^{14} \mathrm{C}\right] \mathrm{Gal}(0.1 \mu \mathrm{Ci})$. BSA $(1 \mathrm{mg} / \mathrm{ml})$ was added to incubations that contained partially purified transferase.

$\beta-N$-Acetylglucosaminyltransferase incubations were performed with either $N$-acetyllactosamineSynsorb or $\beta$-D-GlcNAc( 1,3$)-\beta-\mathrm{D}-\mathrm{Gal}(1,4)-\beta-\mathrm{D}-\mathrm{Glc}-$ Synsorb beads as acceptors ( $1 \mathrm{nmol}$ oligosaccharide/ mg beads), and the following mixture: $20 \mathrm{mM} \mathrm{Mes,} \mathrm{pH}$ $6.1,2 \mathrm{mM} \mathrm{MnCl}_{2}, 0.5 \%(\mathrm{v} / \mathrm{v})$ Triton $\mathrm{X}-100,2 \mathrm{mM} \beta$ mercaptoethanol, and $0.15 \mathrm{mM}$ UDP- $\left[{ }^{14} \mathrm{C}\right] \mathrm{GlcNAc}$ $(0.1 \mu \mathrm{Ci})$.

$\alpha(1,2)$-Fucosyltransferase from porcine salivary glands was assayed according to Beyer et al. (11) using $N$-acetyllactosamine-Synsorb as acceptor $(1 \mathrm{nmol}$ disaccharide/ $\mathrm{mg}$ beads). Incubations contained the following substances: $50 \mathrm{~mm}$ sodium cacodylate, $\mathrm{pH} 6.0$, $20 \mathrm{mM} \mathrm{MnCl}_{2}, 0.5 \mathrm{mg} / \mathrm{ml} \mathrm{BSA}, 0.19 \mathrm{mM}$ GDP-[ $\left.{ }^{14} \mathrm{C}\right] \mathrm{Fuc}$ 
$(0.7 \mathrm{mCi} / \mathrm{mmol})$, and $5 \mathrm{mU}$ of purified enzyme $(1 \mathrm{U}$ transfers $1 \mu \mathrm{mol}$ of L-Fuc per minute).

$\alpha(2,6)$-Sialyltransferase from rat liver was assayed as described by Weinstein et al. (12), with $N$-acetyllactosamine-Synsorb beads as acceptor substrate (1 $\mathrm{nmol}$ disaccharide/mg beads) in addition to the following components: $75 \mathrm{mM}$ sodium cacodylate, $\mathrm{pH}$ 6.0, $0.75 \%(\mathrm{v} / \mathrm{v})$ Triton X-100, $1.25 \mathrm{mg} / \mathrm{ml} \mathrm{BSA}, 0.2 \mathrm{mM}$ CMP- $\left[{ }^{14} \mathrm{C}\right.$ NeuNAc $(1.8 \mathrm{mCi} / \mathrm{mmol})$, and $5 \mathrm{mU}$ of $\mathrm{pu}$ rified enzyme ( $1 \mathrm{U}$ transfers $1 \mu \mathrm{mol}$ of NeuNAc per minute).

$\alpha(2,3)$-Sialyltransferase from rat liver was assayed exactly as described for the $\alpha(2,6)$-sialyltransferase, except that $0.13 \mathrm{mU}$ of purified enzyme was used.

Transferase assays in the presence of soluble acceptors were carried out exactly as indicated above except that the appropriate concentration of soluble oligosaccharide was used. Following incubation, the entire reaction mixture was spotted on Whatman No. $3 \mathrm{MM}$ paper and subjected to high-voltage paper electrophoresis, as described above.

Glycosidase digestions. The anomeric linkage of oligosaccharide-Synsorb beads that had been subjected to the action of glycosyltransferases was determined by treatment with various exoglycosidases. Radioactively labeled beads ( $2 \mathrm{mg}$ ) were incubated in a total volume of $0.1 \mathrm{ml}$ at $37^{\circ} \mathrm{C}$ for 4-6 $\mathrm{h}$, as follows: $0.25 \mathrm{U}$ of coffee hean $\alpha$-galactosidase in $50 \mathrm{~mm}$ citrate, $\mathrm{pH}$ $6.1 ; 0.1 \mathrm{U}$ of bovine testicular $\beta$-galactosidase in 50 mM citrate, $\mathrm{pH} 4.3 ; 1.0 \mathrm{U}$ of Aspergillus $\beta$-galactosidase in $50 \mathrm{~mm}$ citrate, $\mathrm{pH} 5.0 ; 10 \mathrm{U}$ of $E$. coli $\beta$-galactosidase in $50 \mathrm{mM}$ phosphate, $\mathrm{pH} 7.3$; and $0.25 \mathrm{U}$ of beef kidney $\beta$ - $N$-acetylglucosaminidase in $50 \mathrm{mM}$ citrate, $\mathrm{pH} 5.0$. $A$ unit is defined as the amount of enzyme that hydrolyzes $1 \mu \mathrm{mol}$ of terminal nonreducing monosaccharide per minute. Digestions were stopped by heating the samples at $100^{\circ} \mathrm{C}$ for $5 \mathrm{~min}$. The beads were centrifuged and the supernatant solutions were carefully removed for scintillation counting. After being washed repeatedly with $1 \mathrm{ml} \mathrm{H}_{2} \mathrm{O}$, the beads were resuspended in $0.4 \mathrm{ml} \mathrm{H}_{2} \mathrm{O}$ and the amount of radioactivity still covalently attached to the beads was determined.

Affinity chromatography of $\beta$-galactosyltransferases on $\beta$-GlcNAc-Synsorb beads. $\beta$-GlcNAc-Synsorb beads ( $1 \mathrm{nmol}$ monosaccharide/mg beads) were washed repeatedly with distilled water, degassed under vacuum for 5-10 $\mathrm{min}$, and packed into a 20-ml plastic syringe. The column was equilibrated by washing with 5 bed vol of buffer I, consisting of $20 \mathrm{~mm}$ Hepes, $\mathrm{pH} 7.0,150$ $\mathrm{mM} \mathrm{NaCl}, 5 \mathrm{mM} \mathrm{MnCl}, 0.4 \%$ (v/v) Lubrol PX, 25\% glyecrol, and $1 \mathrm{mM} U \mathrm{UMP}$; the column was kept at $4^{\circ} \mathrm{C}$ throughout the procedure. Bovine milk galactosyltransferase $(0.12 \mathrm{U}$ of enzyme dissolved in $1 \mathrm{ml}$ of buffer I) was applied to the column and allowed to interact with the adsorbent for $1 \mathrm{~h}$, and the beads were washed with 5 bed vol of buffer I. A second wash was carried out with buffer I containing $0.5 \mathrm{M} \mathrm{NaCl}$ (buffer II) in order to remove weakly interacting proteins. Finally, the column was eluted with buffer II in which $\mathrm{MnCl}_{2}$ and UMP had been omitted (buffer III). Fractions collected in the course of the chromatography were assayed for galactosyltransferase activity as described above. Aliquots were desalted, particularly to remove UMP prior to assay, by lowspeed centrifugation through small columns of Sephadex G-25 medium (prepared in 3-ml plastic syringes)

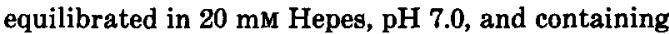
$0.1 \mathrm{mg} / \mathrm{ml}$ BSA. The $\beta$-GlcNAc-Synsorb column was regenerated by washing with 10 bed vol of buffer III, followed by equilibration in buffer I.

For the separation of the Ehrlich tumor cell $\alpha$ - and $\beta$-galactosyltransferase activities, $20 \mathrm{ml}$ of the Lubrol extract $(0.25 \mathrm{mg}$ of protein $/ \mathrm{ml}$ ), adjusted to $5 \mathrm{mM}$ $\mathrm{MnCl}_{2}$ and $1 \mathrm{mM}$ UMP, were loaded on the $\beta$-GlcNAcSynsorb column. The material was allowed to interact within the column for $1 \mathrm{~h}$ and elution was carried out as described above. Assays for $\alpha$ - and $\beta$-galactosyltransferases were conducted in the presence of LacNAc-Synsorb and $\beta$-GlcNAc-Synsorb beads, respectively.

Analytical techniques. Protein concentration was estimated by the Amidoschwarz dye binding method (13) using BSA as standard. Neutral sugars were determined by the phenol sulfuric acid colorimetric method (14).

\section{RESULTS}

\section{Characteristics of the $\beta$ - Galactosyltransferase Assay Employing Insoluble Acceptors}

Simple oligosaccharides were employed in the soluble assay as acceptor substrates. Quantitation of transferase activity was conducted by measuring the radioactivity incorporated into the reaction products and subtracting the background obtained with control incubations. The results of a typical analysis are presented in Fig. 1. Varying concentrations of $\mathrm{N}$-acetylglucosamine were incubated with commercial bovine milk $\beta$-galactosyltransferase in the presence of UDP- $\left[{ }^{14}\right]$ Gal. After $1 \mathrm{~h}$, the entire reaction mixtures were subjected to highvoltage paper electrophoresis. Negatively charged molecules (UDP-Gal and Gal-1phosphate) migrated toward the anode, whereas neutral substances such as the reaction product(s) and $\left[{ }^{14} \mathrm{C}\right] \mathrm{Gal}$ resulting from nucleotide-sugar breakdown remained near the origin. Replotting the data in Fig. 1 (inset) shows that incorporation 


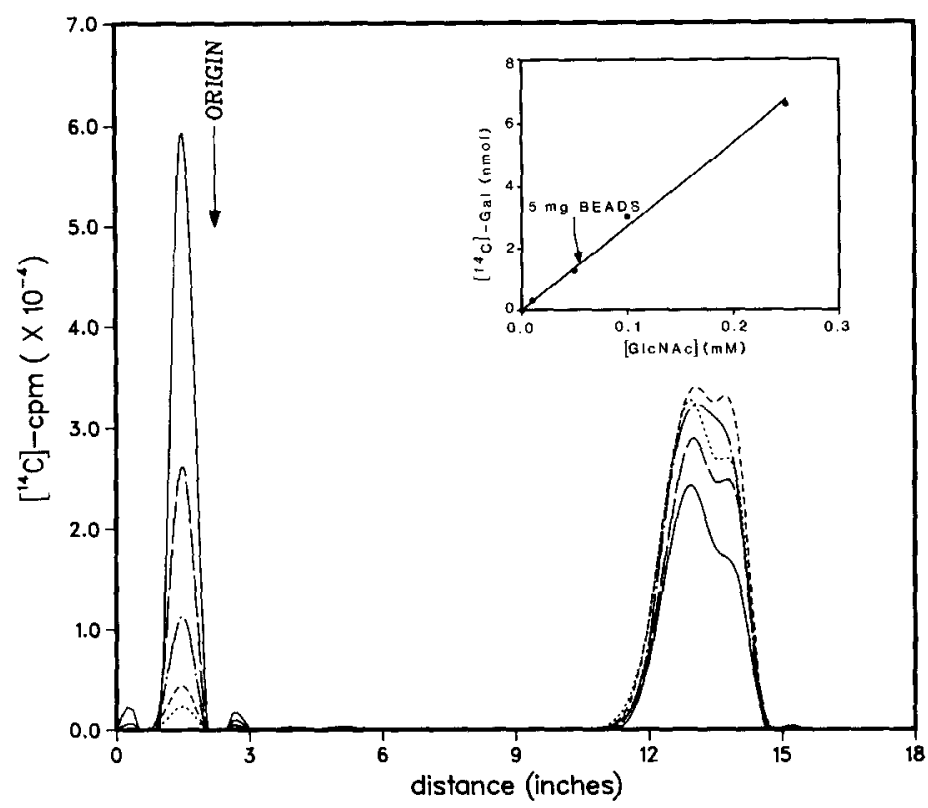

FIG. 1. High-voltage paper electrophoresis of bovine milk $\beta$-galactosyltransferase reaction products. Incubations contained the following components in a final volume of $0.1 \mathrm{ml}: 50 \mathrm{mM}$ cacodylate buffer, pH 7.4, $25 \mathrm{mM} \mathrm{MnCl}_{2} 0.5 \%$ (v/v) Triton X-100, $1 \mathrm{mg} / \mathrm{ml} \mathrm{BSA,} 0.23 \mathrm{~mm} \mathrm{UDP}-\left[{ }^{14} \mathrm{C}\right] \mathrm{Gal}(0.1 \mu \mathrm{Ci}), 0.5$ $\mathrm{mU}$ of bovine milk galactosyltransferase, and varying concentrations of soluble GlcNAc (in $\mathrm{mM}$ ): 0 $(\cdots), 0.01(--), 0.05(-\cdots), 0.1(--)$, and $0.25(-)$. Inset: Data were replotted so that the incorporation of $\left[{ }^{14} \mathrm{C}\right] \mathrm{Gal}$ was expressed as a function of the concentration of soluble monosaccharide. The arrow indicates the amount of label incorporated into an identical incubation using $5 \mathrm{mg}$ of $\beta$-GlcNAc-Synsorb beads: All reactions were conducted at $37^{\circ} \mathrm{C}$ for $1 \mathrm{~h}$.

of radioactive Gal into the transferase reaction product(s) is linear with the concentration of soluble acceptor GlcNAc.

An identical incubation using $5 \mathrm{mg}$ of $\beta$ GlcNAc-Synsorb beads ( $1 \mathrm{nmol}$ monosaccharide/mg beads) resulted in the net incorporation of $1.45 \pm 0.09 \mathrm{nmol}$ of labeled $\mathrm{Gal}$ (inset, arrow) which corresponds to a GleNAc concentration of approximately $0.05 \mathrm{~mm}$. Thus, the soluble and the immobilized $\beta$-GlcNAc units exhibited comparable acceptor activity in the $\beta$-galactosyltransferase assay. The metal requirement for the bovine milk $\beta$-galactosyltransferase reaction with the $\beta$-GlcNAc beads as the acceptor is shown in Table I. The need for divalent cations was manifested by the lack of sugar transfer both in the absence of $\mathrm{MnCl}_{2}$ and in the presence of EDTA. In addition, calcium ions failed to substitute for manganese, while magnesium only partially restores activity, as has been shown previously in a soluble acceptor system

\section{TABLE I}

Bovine Milk Galactosyltransferase Assay UsING $\beta$-GlcNAc-SYNSORB BEADS (5 mg)

\begin{tabular}{lrc}
\hline & \multicolumn{2}{c}{$\left[{ }^{14} \mathrm{C}\right] \mathrm{Gal}$ incorporation } \\
\cline { 2 - 3 } Incubation system & $\mathrm{cpm}$ & $\%$ \\
\hline Complete $^{a}$ & 15,950 & 100 \\
- Enzyme $_{-}$ & 200 & 1.2 \\
$-\mathrm{MnCl}_{2}$ & 270 & 1.7 \\
$-\mathrm{MnCl}_{2}+\mathrm{MgCl}_{2}{ }^{b}$ & 1,178 & 7.4 \\
$-\mathrm{MnCl}_{2}+\mathrm{CaCl}_{2}{ }^{\circ}$ & 271 & 1.7 \\
$-\mathrm{MnCl}_{2}+\mathrm{EDTA}^{d}$ & 209 & 1.3 \\
$+\alpha-\mathrm{Lactalbumin}^{e}$ & 2,525 & 15.8 \\
\hline
\end{tabular}

${ }^{a}$ Reaction mixture contained $50 \mathrm{mM}$ cacodylate $(\mathrm{pH}$ 7.4), $25 \mathrm{mM} \mathrm{MnCl}_{2}, 2 \mathrm{mM} \beta$-mercaptoethanol, $0.5 \%$ Triton X-100, $1 \mathrm{mg} / \mathrm{ml}$ BSA, $0.31 \mathrm{mM}$ UDP $-\left[{ }^{14} \mathrm{C}\right] \mathrm{Gal}$ $(0.1 \mu \mathrm{Ci})$, and $0.5 \mathrm{mU}$ of bovine milk galactosyltransferase in a total volume of $0.1 \mathrm{ml}$, for $1 \mathrm{~h}$ at $37^{\circ} \mathrm{C}$.

${ }^{b} 25 \mathrm{~mm} \mathrm{MgCl}$.

c $25 \mathrm{mM} \mathrm{CaCl}_{2}$.

i 5 mM EDTA.

* $1 \mathrm{mg} / \mathrm{ml} \alpha$-lactalbumin. 


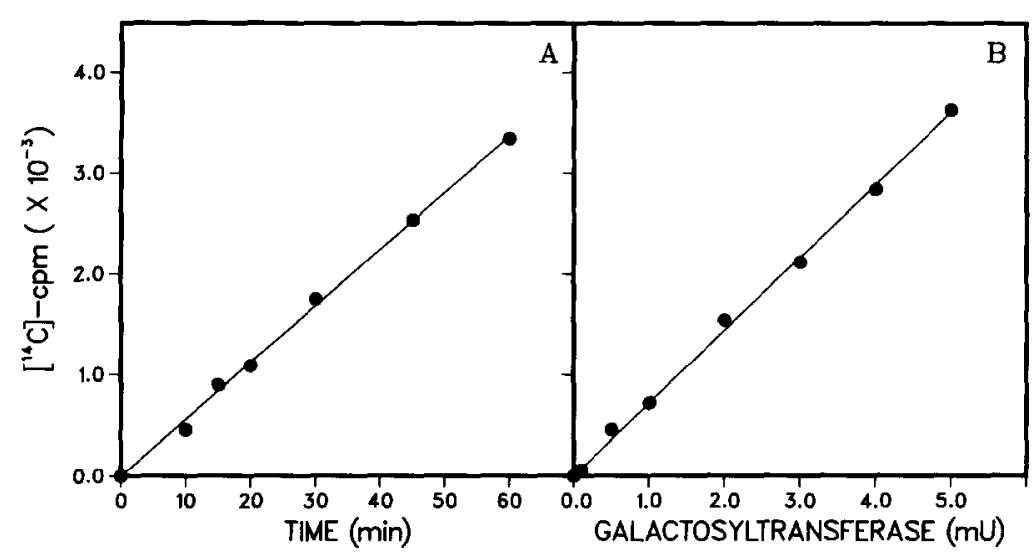

FIG. 2. Galactosyltransferase assays using $\beta$-GlcNAc-Synsorb beads. Incubation mixtures were identical to that described in the legend to Fig. 1 and contained $5 \mathrm{mg}$ of $\beta$-GleNAc-Synsorb beads. (A) Incorporation of labeled $\mathrm{Gal}$ with time ( $0.5 \mathrm{mU}$ of bovine milk galactosyltransferase per assay).

(B) Dependence on protein concentration (incubation times were $10 \mathrm{~min}$ ).

(15). Furthermore, the effect of $\alpha$-lactalbumin, a protein that modifies the acceptor specificity of the transferase from GleNAc to Glc in the soluble assay (16), was observed with $\beta$-GlcNAc-Synsorb beads in that transfer of labeled Gal to the GleNAc acceptor was inhibited over sixfold (Table I). In Fig. 2, the insoluble assay was shown to be linear with time within the period of $60 \mathrm{~min}$, at an enzyme concentration of 0.5 $\mathrm{mU}(\mathrm{A})$, and to be linear with the concentration of enzyme, when varied between 0.1 and $5 \mathrm{mU}$ for a 10 -min incubation period (B).

The anomeric linkage of the radioactive product isolated after incubation of bovine milk $\beta$-galactosyltransferase with $\beta$ GlcNAc-Synsorb beads and UDP- $\left[{ }^{14} \mathrm{C}\right] \mathrm{Gal}$ was determined by digestion with various $\alpha$ - and $\beta$-galactosidases. The results are presented in Table II. As one would expect from the specificity of the transferase (17), coffee bean $\alpha$-galactosidase did not release labeled Gal into the supernatant solution, whereas bovine testicular $\beta$-galactosidase digested almost $90 \%$ of the radioactivity originally incorporated into the $\beta$-GlcNAc beads. Aspergillus and E. coli $\beta$-galactosidases also liberated over $50 \%$ of the label, although they were not as efficient as the bovine testis $\beta$-galactosidase.

Likewise, transferase reaction products obtained by incubation with soluble $N$ - acetylglucosamine as the acceptor substrate were analyzed by descending paper chromatography (data not shown). The results confirmed that $N$-acetyllactosamine was the only product formed.

Control incubations, in the absence of enzyme, consistently gave very low background incorporation compared to the sol-

\section{TABLE II}

Glycosidase Digestions of $\beta$-GleNAc-SynsorB BEads INCUBated WITH Bovine MILK $\beta$-GalaCtOSYLTRANSFERASE

\begin{tabular}{|c|c|c|c|c|}
\hline \multirow[b]{3}{*}{ Galactosidase } & \multicolumn{4}{|c|}{ Radioactivity } \\
\hline & \multicolumn{2}{|c|}{$\begin{array}{l}\text { Released to } \\
\text { supernatant }\end{array}$} & \multicolumn{2}{|c|}{$\begin{array}{l}\text { Remaining } \\
\text { in the beads }\end{array}$} \\
\hline & cpm & $\%$ & cpm & $\%$ \\
\hline $\begin{array}{l}\text { Coffee bean } \\
(\alpha)^{a}\end{array}$ & 210 & 9 & 2170 & 91 \\
\hline $\begin{array}{l}\text { Bovine testis } \\
\qquad(\beta)^{b}\end{array}$ & 2205 & 87 & 325 & 13 \\
\hline $\begin{array}{l}\text { Aspergillus } \\
(\beta)^{c} \\
\text { E. coli }(\beta)^{d}\end{array}$ & $\begin{array}{l}1990 \\
1625\end{array}$ & $\begin{array}{l}69 \\
69\end{array}$ & $\begin{array}{l}890 \\
730\end{array}$ & $\begin{array}{l}31 \\
31\end{array}$ \\
\hline
\end{tabular}

${ }^{a} 2.5 \mathrm{U} / \mathrm{ml}$ in $50 \mathrm{mM}$ citrate buffer, pH 6.1.

${ }^{b} 1 \mathrm{U} / \mathrm{ml}$ in $50 \mathrm{mM}$ citrate buffer, $\mathrm{pH} 4.3$.

${ }^{c} 10 \mathrm{U} / \mathrm{ml}$ in $50 \mathrm{~mm}$ citrate buffer, $\mathrm{pH} 4.0$.

${ }^{d} 100 \mathrm{U} / \mathrm{ml}$ in $50 \mathrm{mM}$ phosphate buffer, pH 7.3. 
uble assay, which exhibited values 5- to 10fold higher (data not shown).

\section{Glycosyltransferase Activities in \\ Ehrlich Tumor Cells Detected with \\ Synsorb Beads}

Membrane fractions from Ehrlich ascites tumor cells extracted with detergent were analyzed for their ability to catalyze transfer of Gal and GlcNAc to insoluble oligosaccharide acceptors. Table III summarizes the results of the incubations. Based on the incorporation of radiolabeled sugars and the sensitivity of the resulting products to glycosidase digestions, we conclude that Ehrlich cells possess both $\alpha$ - and $\beta$-galactosyltransferase as well as $\beta-N$ acetylglucosaminyltransferase activities toward exogenous acceptors. The insoluble structures containing one and two $N$-acetyllactosamine repeating units were capable of incorporating Gal in $\alpha$-linkage when UDP- $\left[{ }^{14} \mathrm{C}\right] \mathrm{Gal}$ was provided as the donor substrate, a finding that explains the presence of $G$. simplicifolia ${\mathrm{I}-\mathrm{B}_{4}}_{4}$ isolectinreactive glycans on the plasma membrane of the Ehrlich cells (18). Recently, this transferase was purified to homogeneity (19). Likewise, the two substrates indicated above incorporated $\left[{ }^{14} \mathrm{C}\right] \mathrm{GlcNAc}$ in $\beta$-linkage when UDP- $\left[{ }^{14} \mathrm{C}\right] \mathrm{GlcNAc}$ was the donor substrate. This observation is in agreement with structural studies on the surface glycoproteins of Ehrlich tumor cells, which suggested the presence of poly- $N$-acetyllactosaminyl chains (20). A second and separate $N$-acetylglucosaminyltransferase appeared to act on the trisaccharide $\beta-\mathrm{D}$ GlcNAc(1,3)- $\beta$-D-Gal(1,4) $\beta$-D-Glc, since incorporation of $\left[{ }^{14} \mathrm{C}\right] \mathrm{GlcNAc}$ in $\beta$-linkage was observed. A similar oligosaccharide was employed to probe for the $\beta(1,6)-N$ acetylglucosaminyltransferase activity responsible for the synthesis of blood group I-active structures in hog gastric mucosa (21). In addition, $\beta$-D-GlcNAc and $\beta$-D-

TABLE III

Glycosyltransferase Activities in Detergent-Solubilized Extracts of Ehrlich Ascites Tumor Cells

\begin{tabular}{|c|c|c|c|}
\hline Acceptor structure ${ }^{a}$ & $\begin{array}{l}\text { Nucleotide-sugar } \\
\text { donor }\end{array}$ & $\begin{array}{l}{ }^{14} \mathrm{C} \text { Incorporation }{ }^{b} \\
\text { (cpm/5 mg beads) }\end{array}$ & Glycosidase sensitivity ${ }^{c}$ \\
\hline$\beta$-D-GlcNAc & $\mathrm{UDP}-\left[{ }^{14} \mathrm{C}\right] \mathrm{Gal}$ & 27,150 & $\beta$-Galactosidase ${ }^{d}$ \\
\hline$\beta-\mathrm{D}-\mathrm{Gal}(1,4)-\beta-\mathrm{D}-\mathrm{GlcNAc}$ & $\mathrm{UDP}-\left[{ }^{14} \mathrm{C}\right] \mathrm{Gal}$ & 15,400 & $\alpha$-Galactosidase \\
\hline $\begin{array}{l}\beta \text {-D-GleNAc(1,3)- } \beta \text {-D-Gal-(1,4)- } \\
\beta \text {-D-Glc }\end{array}$ & $\mathrm{UDP}-\left[{ }^{14} \mathrm{C}\right] \mathrm{Gal}$ & 25,400 & $\beta$-Galactosidase \\
\hline $\begin{array}{c}\beta \text {-D-Gal }(1,4)-\beta \text {-D-GlcNAc- }(1,3)- \\
\beta \text {-D-Gal }(1,4)-\beta \text {-D-GlcNAc }\end{array}$ & UDP- $\left[{ }^{14} \mathrm{C}\right] \mathrm{Gal}$ & 16,000 & $\alpha$-Galactosidase \\
\hline$\beta-\mathrm{D}-\mathrm{Gal}(1,4)-\beta-\mathrm{D}-\mathrm{GleNAc}$ & $\begin{array}{l}\text { UDP- } \\
{\left[{ }^{14} \mathrm{C}\right] \mathrm{GleNAc}}\end{array}$ & 2,250 & $\beta-N$-Acetylglucosaminidase \\
\hline $\begin{array}{l}\beta \text {-D-GleNAc(1,3)- } \beta \text {-D-Gal-(1,4)- } \\
\beta \text {-D-Gle }\end{array}$ & $\begin{array}{l}\text { UDP- } \\
{\left[{ }^{14} \mathrm{C}\right] \mathrm{GlcNAc}}\end{array}$ & 3,250 & $\beta-N$-Acetylglucosaminidase \\
\hline $\begin{array}{c}\beta \text {-D-Gal }(1,4)-\beta-\mathrm{D}-\mathrm{GleNAc}-(1,3)- \\
\beta-\mathrm{D}-\mathrm{Gal}(1,4)-\beta-\mathrm{D}-\mathrm{GlcNAc}\end{array}$ & $\begin{array}{l}\text { UDP- } \\
{\left[{ }^{[4} \mathrm{C}\right] \mathrm{GICNAc}}\end{array}$ & 2,750 & $\beta$ - $N$-Acetylglucosaminidase \\
\hline
\end{tabular}

\footnotetext{
a All carbohydrate structures indicated were covalently bound to Synsorb beads (1 nmol oligosaccharide/ mg beads).

${ }^{b}$ Incubations were carried out as described under Experimental Procedures and contained $15.8 \mathrm{nmol}$ of UDP- $\left[{ }^{14} \mathrm{C}\right] \mathrm{Gal}(0.1 \mu \mathrm{Ci})$ or $15.3 \mathrm{nmol}$ of UDP- $\left[{ }^{14} \mathrm{C}\right] \mathrm{G}$ leNAc $(0.1 \mu \mathrm{Ci})$, respectively. The amount of protein from Ehrlich cells was $0.35 \mathrm{mg}$ in all incubations conducted for $1 \mathrm{~h}$ at $37^{\circ} \mathrm{C}$. Error in triplicate determinations was estimated to be $\leq 10 \%$.

- The following glycosidascs were employed: coffee bean $\alpha$-galactosidase, bovine testis $\beta$-galactosidase, and beef kidney $\beta-N$-acetylglucosaminidase. Digestions were performed as indicated under Experimental Procedures,

${ }^{d}$ The amount of label sensitive to $\alpha$-galactosidase was determined to be $\leqslant 15 \%$.
} 
GleNAc(1,3)- $\beta$-D-Gal(1,4)- $\beta$-D-Glc were good acceptors for the $\beta$-galactosyltransferase activity which presumably is responsible for the synthesis of the $N$-acetyllactosamine repeating units present in Ehrlich cells.

\section{Methylation Analysis of Transferase Reaction Products}

A procedure for the permethylation of oligosaccharide-Synsorb beads based on Hakomori's method (22) was developed. In particular, we were interested in investigating the linkage specificity of glycosyltransferases which utilize $N$-acetyllactosamine as the acceptor substrate. We took advantage of the known fact that bovine milk $\beta$-galactosyltransferase incorporates radioactive $\mathrm{Gal}$ from $\mathrm{UDP}-\left[{ }^{14} \mathrm{C}\right] \mathrm{Gal}$ into
GleNAc to form $\beta$-D-Gal(1,4)-D-GleNAc (see above), and we utilized the resulting ${ }^{14} \mathrm{C}$-labeled disaccharide to determine the linkage formed by the action of glycosyltransferases acting on this acceptor. Initially, we permethylated $\beta-\mathrm{D}-\left[{ }^{14} \mathrm{C}\right] \mathrm{Gal}(1,4)$ $\beta$-D-GlcNAc-Synsorb beads that were prepared enzymatically, hydrolyzed the methylated oligosaccharide, and analyzed the labeled fragments. Figure 3 shows thinlayer chromatograms in which partially methylated $\mathrm{D}$-galactose derivatives were separated. The enzymatically synthesized LacNAc-Synsorb beads gave rise to a single peak of radioactivity that comigrated with 2,3,4,6-tetra-O-methylgalactose (Fig. $3 \mathrm{~A}$ ), thus indicating terminal unsubstituted galactose. To test the applicability of the method, we used identical LacNAcSynsorb beads to act as acceptors for por-

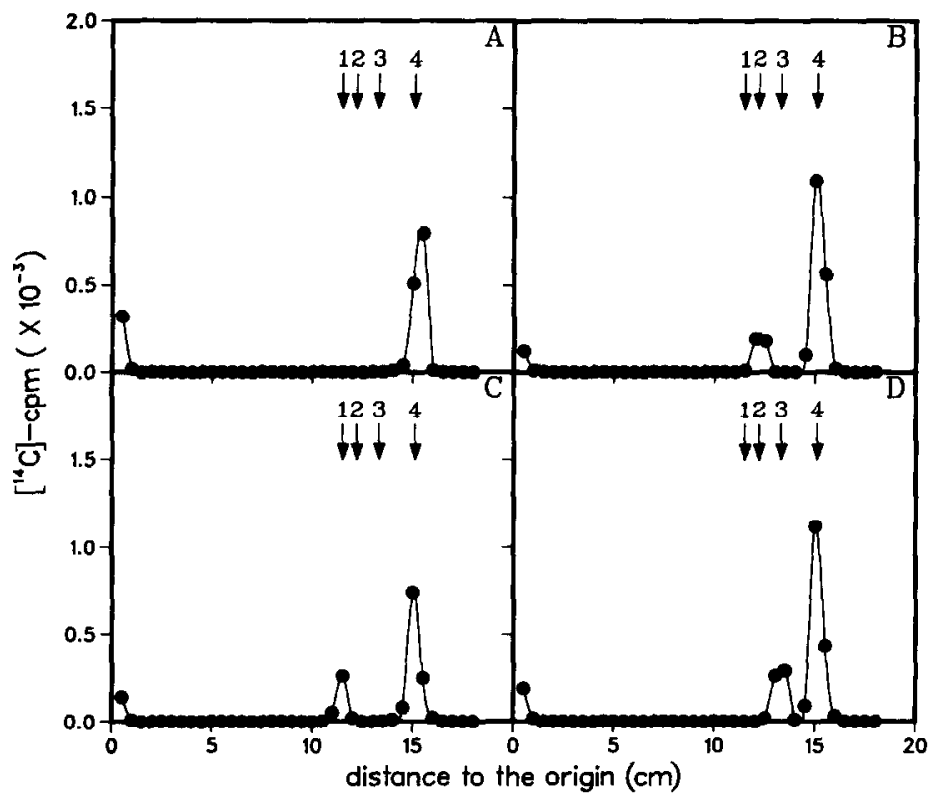

FIG. 3. Thin-layer chromatography of partially methylated $\left[{ }^{14} \mathrm{C}\right]$ galactoses. $N-\left[{ }^{14} \mathrm{C}-\mathrm{Gal}\right]-$ Acetyllactosamine-Synsorb beads, prepared as described under Experimental Procedures, were utilized as acceptor substrates for a variety of glycosyltransferases. The resulting insolubilized oligosaccharides were subjected to methylation, hydrolysis, and analysis by TLC in benzene:acetone: water: $\mathrm{NH}_{4} \mathrm{OH}$ (50:200:3:1.5:, v/v/v/v), as indicated under Experimental Procedures. (A) Untreated acceptor $\beta-\mathrm{D}-\left[{ }^{14} \mathrm{C}\right] \mathrm{Gal}(1,4)-\beta-\mathrm{D}-\mathrm{GlcNAc}-$ Synsorb. (B) Product from the porcine submaxillary gland $\alpha(1,2)$-fucosyltransferase incubation. (C) Product from the rat liver $\alpha(2,6)$-sialyltransferase reaction. (D) Product from the rat liver $\alpha(2,3)$-sialyltransferase reaction. Arrows indicate the migration of standards: 1, 2,3,4-tri- $O$-methylgalactose; 2, 3,4,6-tri- $O$-methylgalactose; 3, 2,4,6-tri- $O$-methylgalactose; 4, 2,3,4,6-tetra-O-methylgalactose. 
cine submaxillary gland $\alpha(1,2)$-fucosyltransferase (Fig. 3B), rat liver $\alpha(2,6)$-sialyltransferase (Fig. $3 \mathrm{C}$ ), and rat liver $\alpha(2,3)$-sialyltransferase (Fig. 3D). In all three cases, we observed a major peak that corresponded to tetra- $O$-methylgalactose and a minor peak accounting for $17-25 \%$ of the total radioactivity that comigrated with 3,4,6-tri-O-methylgalactose (Fig. 3B), 2,3,4-tri-O-methylgalactose (Fig. 3C), and 2,4,6-tri-O-methylgalactose (Fig. 3D), respectively.

According to the results presented in Table III, Ehrlich tumor cells exhibited two transferase activitics that act on LacNAcSynsorb beads: one transferred $\mathrm{Gal}$ in $\alpha$ linkage, and the second incorporated GlcNAc in $\beta$-linkage. To further investigate the specificity of these two enzymes, we carried out incubations with detergent extracts of Ehrlich tumor cells in the presence of $\left[{ }^{14} \mathrm{ClLacNAc}-\right.$ Synsorb and either UDP-Gal or UDP-GlcNAc. The $\alpha$-galac tosyltransferase reaction products (LacNAc-Synsorb beads, and UDP-Gal incu- bation) afforded one peak accounting for $30 \%$ of the total radioactivity and comigrating with 2,4,6-tri-O-methylgalactose, in addition to tetra- $O$-methylgalactose (Fig. 4A). Similarly, the reaction product obtained by incubating radioactive LacNAc-Synsorb and UDP-GlcNAc produced a small peak that comigrated with 2,4,6-tri- $O$-methylgalactose (12\% of the total radioactivity) and a larger peak coinciding with 2,3,4,6-tetra-O-methylgalactose (Fig. 4B). We concluded that the latter enzyme was the $\beta(1,3)-N$-acetylglucosaminyltransferase capable of initiating and maintaining the synthesis of poly- $N$-acetyllactosamine chains.

To further substantiate this possibility, we incubated unlabeled LacNAc-Synsorb with UDP- $\left[{ }^{14} \mathrm{C}\right] \mathrm{GlcNAc}$ in the absence and in the presence of cold UDP-Gal. Alternatively, we treated $\beta$-GlcNAc-Synsorb beads with UDP- $\left[{ }^{14} \mathrm{C}\right] \mathrm{Gal}$ in the absence and in the presence of cold UDP-GlcNAc. The results are presented in Table IV. In both cases, coincubation with UDP-Gal and

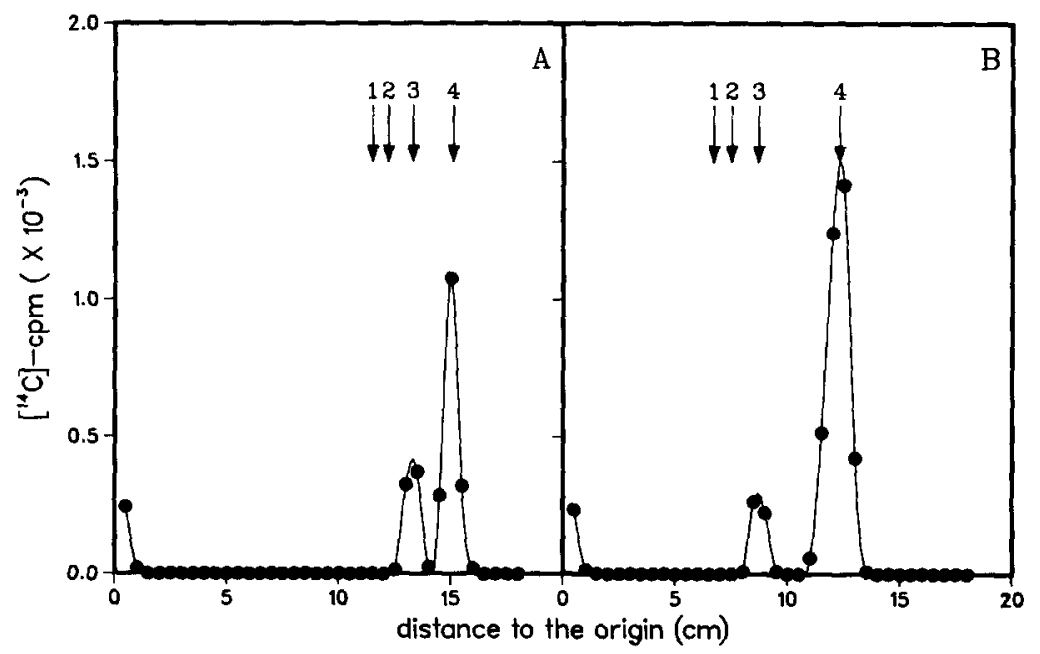

Fig. 4. Thin-layer chromatography of partially methylated galactoses obtained by incubation of radioactive LacNAc-Synsorb beads with glycosyltransferases from Ehrlich tumor cell detergent extracts. $\left.\mathrm{N}-{ }^{14} \mathrm{C}-\mathrm{Gal}\right]$ Acetyllactosamine-Synsorb beads were incubated with detergent extracts of Ehrlich tumor cell microsomes in the presence of UDP-Gal (A) or UDP-GlcNAc (B). The resulting oligosaccharide-Synsorb products were methylated, hydrolyzed, and analyzed by TLC as described under Experimental Procedures. (A) $\alpha(1,3)$-Galactosyltransferase activity in Ehrlich tumor cells. (B) Ehrlich tumor cell $\beta(1,3)-N$-acetylglucosaminyltransferase activity. Arrows indicate the position of selected standards: 1, 2,3,4-tri- $O$-methylgalactose; 2, 3,4,6-tri- $O$-methylgalactose; 3, 2,4,6-tri- $O$ methylgalactose; 4, 2,3,4,6-tetra- $O$-methylgalactose. 
TABLE IV

In Vitro Biosynthesis of Polylactosamine Chains in Ehrlich Ascites Tumor Cells

\begin{tabular}{|c|c|c|c|}
\hline \multicolumn{2}{|r|}{ Incubation $^{a}$} & \multicolumn{2}{|c|}{${ }^{14} \mathrm{C}$ incorporation } \\
\hline Acceptor & Donor & $\mathrm{cpm} / 5 \mathrm{mg}$ beads & $\%$ \\
\hline 1. $\beta$-D-GlcNAc & $0.3 \mathrm{nmol}$ UDP- $\left[{ }^{14} \mathrm{C}\right] \mathrm{Gal}$ & 12,280 & 100 \\
\hline 2. $\beta$-D-GlcNAc & $0.3 \mathrm{nmol} \mathrm{UDP}-\left[{ }^{14} \mathrm{C}\right] \mathrm{Gal}+60 \mathrm{nmol}$ UDP-Gal & 615 & 5 \\
\hline 3. $\beta$-D-GlcNAe & $0.3 \mathrm{nmol}$ UDP $-\left[{ }^{14} \mathrm{C}\right] \mathrm{Gal}+60 \mathrm{nmol}$ UDP-GleNAc & 16,685 & 136 \\
\hline 4. $\beta$-D-Gal $(1,4)-\beta-\mathrm{D}-\mathrm{GlcNAc}$ & $0.3 \mathrm{nmol} \mathrm{UDP}-\left[{ }^{14} \mathrm{C}\right] \mathrm{GlcNAc}$ & 965 & 100 \\
\hline 5. $\beta$-D-Gal $(1,4)-\beta-\mathrm{D}-\mathrm{GlcNAc}$ & $0.3 \mathrm{nmol}$ UDP- $\left[{ }^{14} \mathrm{C}\right] \mathrm{GlcNAc}+60 \mathrm{nmol}$ UDP-GleNAc & 48 & 5 \\
\hline 6. $\beta-\mathrm{D}-\mathrm{Gal}(1,4)-\beta-\mathrm{D}-\mathrm{GlcNAc}$ & $0.3 \mathrm{nmol} U \mathrm{UDP}-\left[{ }^{14} \mathrm{C}\right] \mathrm{GlcNAc}+60 \mathrm{nmol} \mathrm{UDP}-\mathrm{Gal}$ & 1,635 & 169 \\
\hline
\end{tabular}

a Acceptor substrates were covalently linked to Synsorb beads ( $1 \mathrm{nmol}$ oligosaccharide/mg beads). Transferase assays were conducted as described under Experimental Procedures using the amounts of UDP-Gal and UDPGlcNAc specified above. Duplicate determinations exhibited an error of less than $10 \%$.

UDP-GlcNAc resulted in larger incorporations than those obtained in control incubations (arbitrarily assigned $100 \%$ ). The synergistic effect suggested that in vitro synthesis of polylactosamine chains had occurred.

\section{Purification of $\beta$-Galactosyltransferases on $\beta$-GlcNAc-Synsorb Beads}

In addition to the utilization of $\beta$ GlcNAc-Synsorb beads as an acceptor substrate for $\beta$-galactosyltransferases, we conceived the possibility of using the Synsorb-derivatized monosaccharide as a specific adsorbent. We applied a sample of commercial bovine milk $\beta$-galactosyltransferase to a column of $\beta$-GlcNAc-Synsorb beads equilibrated in the presence of $\mathrm{MnCl}_{2}$ and UMP. Under these conditions we observed adsorption of the transferase (Fig. 5); binding was relatively strong as judged by the lack of enzyme activity upon washing with high ionic strength buffer (arrow at position A). Elution of the transferase was accomplished by omitting $\mathrm{MnCl}_{2}$ and UMP from the column buffer (arrow at position B). Recovery from the chromatography was over $85 \%$.

To test the utility of the above chromatographic procedure for the separation of $\alpha$ - and $\beta$-galactosyltransferase activities in Ehrlich tumor cells, we loaded a Lubrol PX extract of Ehrlich cells $(0.25 \mathrm{mg}$ protein $/ \mathrm{ml} ; 20 \mathrm{ml}$ total volume) containing both transferases onto a column of $\beta$ -
GlcNAc-Synsorb beads (Fig. 6). It appeared that $\beta$-galactosyltransferase was bound to the affinity adsorbent when $\mathrm{MnCl}_{2}$ and UMP were both present. A small amount of $\beta$-galactosyltransferase passed through the column unretarded, due either to overloading or to the presence of transferase activities with lower affinities for the ligand. Recovery from the column in the fractions eluted in the absence of $\mathrm{MnCl}_{2}$ and UMP (arrow at B) accounted for $80 \%$ of the total enzyme activity applied, and the material was virtually free from $\alpha$-galactosyltransferase activity, although not homogeneous by SDS-PAGE (data not shown).

\section{DISCUSSION}

Oligosaccharide-derivatized Synsorb beads have been used to develop a general procedure for the assay of glycosyltransferase activity. The merit of the method stems from the fact that reaction products are recovered as insoluble material, while the unreacted nucleotide-sugar donor and other soluble components in the incubation mixture are easily removed. The assay allows the separate determination of transfer into endogenous and exogenous acceptors, and typically results in very low background incorporations. When radioactive substrates are employed, analysis of the anomeric linkage in the reaction products is conducted by digestion with specific 


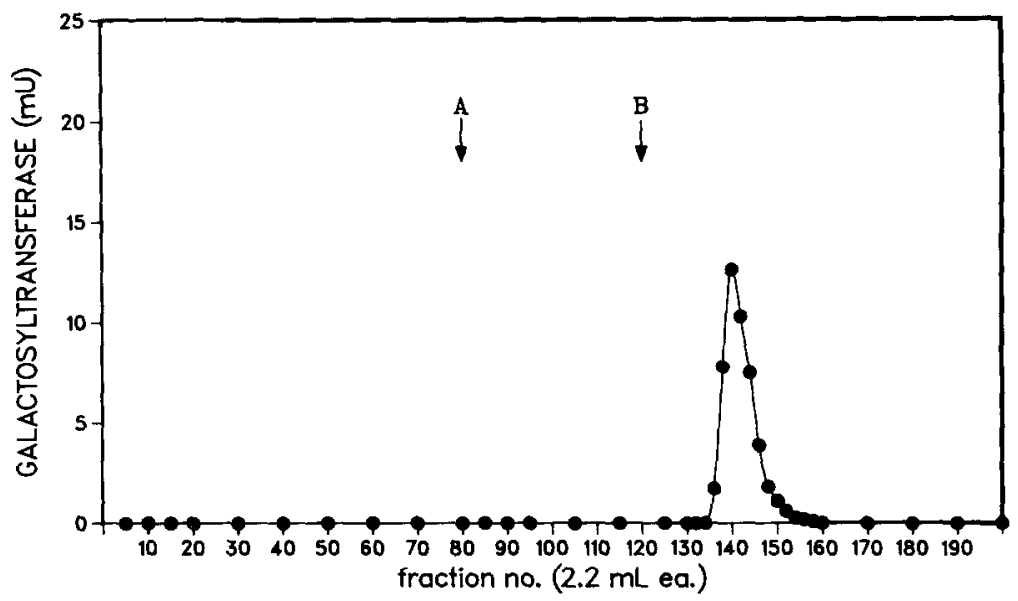

FIG. 5. Affinity chromatography of bovine milk $\beta$-galactosyltransferase on $\beta$-GlcNAc-Synsorb beads. Commercial galactosyltransferase from bovine milk $(0.12 \mathrm{U})$ was applied to a column of $\beta$ GleNAc-Synsorb beads equilibrated with $20 \mathrm{mM} \mathrm{NaCl}, 25 \%$ glycerol, and $1 \mathrm{mM}$ UMP. The transferase was allowed to interact within the column for $1 \mathrm{~h}$, followed by stepwise elution with equilibration buffer, equilibration buffer adjusted to $0.5 \mathrm{M} \mathrm{NaCl}$ (arrow at $\mathrm{A}$ ), and equilibration buffer minus $\mathrm{MnCl}_{2}$ and UMP, and adjusted to $0.5 \mathrm{M} \mathrm{NaCl}$ (arrow at $\mathrm{B}$ ). $\beta$-Galactosyltransferase assays were carried out as described under Experimental Procedures.

exoglycosidases and also by permethylation of the oligosaccharide products followed by hydrolysis from the Synsorb beads. The sensitivity of the assay toward various transferase activities depends on the amount of enzyme added and the specific activity of the radiolabeled donor substrate, provided that a suitable acceptor is used. One limitation of the solid phase assay results from the difficulty of varying the concentration of oligosaccharide-Synsorb beads over a wide range. This prevents the determination of $K_{m}$ values for the acceptor substrate.

Ehrlich ascites tumor cells were shown to contain a number of glycosyltransferases that are involved in the synthesis of $\mathrm{N}$-acetyllactosamine or act on this disaccharide and sequences derived from it. Indeed, an $\alpha(1,3)$-galactosyltransferase that catalyzes the synthesis of $\alpha-\mathrm{D}-\mathrm{Gal}(1,3)-\beta$ $D$-Gal(1,4)-D-GlcNAc has been demonstrated, a finding that accounts for the presence of the Ehrlich cell membrane glycoproteins that interact with the $\alpha-D$ -

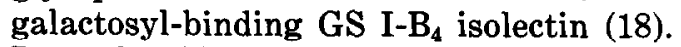
Recently, this $\alpha(1,3)$-galactosyltransferase has been purified to homogeneity (19). A second galactosyltransferase catalyzes the transfer of Gal in $\beta(1,4)$-linkage to GlcNAc and thus appears to be involved in the biosynthesis of complex-type sugar chains in Ehrlich cell glycoproteins (23). Interestingly, at least two separate $N$-acetylglucosaminyltransferase activities have been detected in detergent extracts of Ehrlich cells, one of which is a $\beta(1,3)-N$-acetylglucosaminyltransferase that incorporates a GleNAc group in $\beta(1,3)$-linkage to $N$-acetyllactosamine and appears to be involved in the biosynthesis of poly- $N$-acetyllactosamine chains. A similar activity has been reported in Novikoff ascites cells (24), human serum $(25,26)$, mouse T-lymphoma (27), and baby hamster kidney cells (28). Moreover, this transferase would provide the enzymatic basis for the presence of repeating $3-O-\beta-\mathrm{D}-\mathrm{Gal}(1,4)-\beta-\mathrm{D}-\mathrm{GlcNAc}-1$ units on the cell membrane glycans of Ehrlich tumor cells (20). A second $N$-acetylglucosaminyltransferase activity that utilizes the acceptor $\beta$-D-GlcNAc(1,3)- $\beta$-DGal $(1,4)-\beta$-D-Glc-Synsorb beads has been identified. Although the linkage has not been established, we speculate that the enzyme may be involved in initiating the synthesis of blood group I antigenic chains which contain the branching structure $\beta$ - 


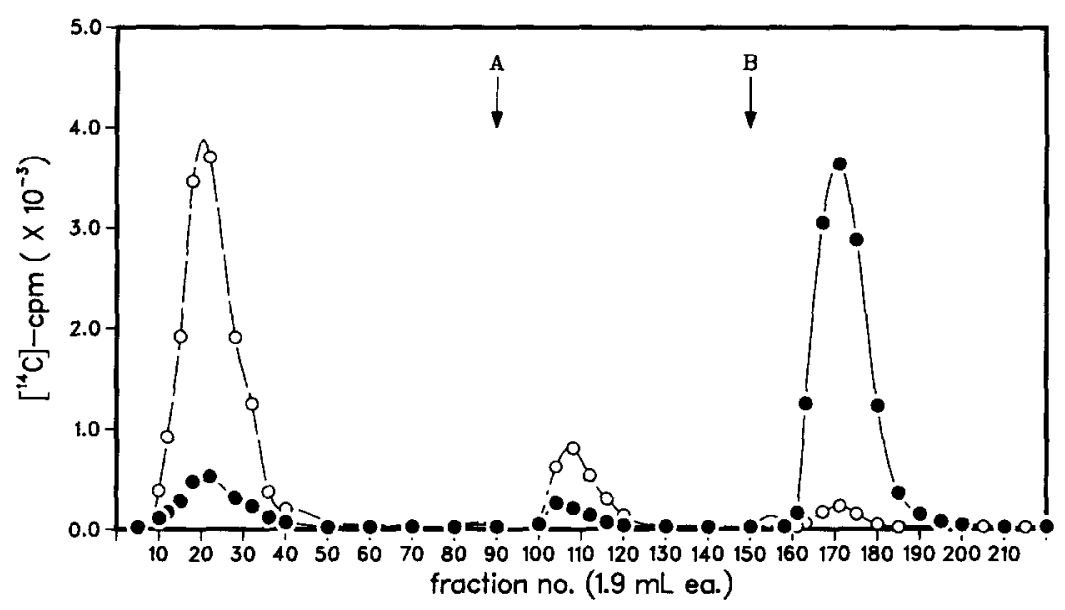

FIG. 6. Separation of $\alpha$ - and $\beta$-galactosyltransferase activities from Ehrlich tumor cells by chromatography on $\beta$-GlcNAc-Synsorb beads. Ehrlich cell microsomal protein solubilized with Lubrol PX (20 ml, $0.25 \mathrm{mg}$ of protein $/ \mathrm{ml}$ ) was applied to a column of $\beta$-GlcNAc-Synsorb beads (prepared in a $20-\mathrm{ml}$ plastic syringe) equilibrated with a buffer containing $\mathbf{M n C l}_{\mathbf{2}}$ and UMP (see Experimental Procedures). The detergent extract was allowed to interact with the column for $1 \mathrm{~h}$. Subsequently, $\beta$-GlcNAc-Synsorb beads were washed in a stepwise fashion with column buffer, column buffer adjusted to $0.5 \mathrm{M} \mathrm{NaCl}$ (arrow at $\mathrm{A}$ ), column buffer without $\mathrm{MnCl}_{2}$ and UMP, and adjusted to $0.5 \mathrm{M}$ $\mathrm{NaCl}$ (arrow at B). $\alpha$-Galactosyltransferase (open circles) and $\beta$-galactosyltransferase (closed circles) activities were assayed as indicated under Experimental Procedures.

D-GlcNAc $(1,3)-[\beta-D-G l c N A c(1,6)]-D-G a l$ (29). Recently, acceptor specificity studies of the corresponding $\beta(1,6)-N$-acetylglucosaminyltransferase from hog gastric mucosa (21) demonstrated that the presence of unsubstituted $\beta-\mathrm{D}-\mathrm{GlcNAc}-(1,3)-\mathrm{D}-$ Gal was a necessary requirement before branching could occur. In Novikoff cells, however, the $\beta(1,6)-N$-acetylglucosaminyltransferase activity appears to be fully capable of using unsubstituted terminal nonreducing $\mathrm{D}-\mathrm{Gal}$ residues as acceptors (24).

Ehrlich tumor cell $\alpha$ - and $\beta$-galactosyltransferases have been separated using chromatography on $\beta$-GlcNAc-Synsorb beads as adsorbent. It has been reported that UDP or UMP considerably enhances the affinity of bovine milk $\beta$-galactosyltransferase for $N$-acetylglucosamine-substituted agarose beads (4), and this appears to be the case for the Ehrlich cell $\beta$-galactosyltransferase as well. On the other hand, $\alpha$-galactosyltransferase exhibits no affinity for the column, in agreement with the observation that GleNAc is not an acceptor substrate for the enzyme (19). Because efficient binding of the $\beta$-galactosyltransferase requires that the enzyme be allowed to interact with the adsorbent for a prolonged period of time, large volumes of sample do not afford very clean separations. There fore, affinity chromatography on $\beta$-GlcNAc-Synsorb beads is most useful only in combination with additional purification procedures.

\section{REFERENCES}

1. Beyer, T. A., SAdLer, J. E., Rearick, J. I., PAULSON, J. C., AND HUL, R. L. (1981) Adv. Enzymol. Relat. Areas Mol. Biol. 52, 23-175.

2. HagOPIAN, A., AND EYLAR, E. H. (1968) Arch. Biochem. Biophys. 128, 422-433.

3. WATKINS, W. M., AND HASSID, W. Z. (1962) J. Biol Chem. 237, 1432-1440.

4. BARker, R., Olsen, K. W., Shaper, J. H., AND HIIL, R. L. (1972) J. Biol. Chem. 247, 7135-7147.

5. SAdler, J. E., BeYer, T. A., OPPENheimer, C. L., Paulson, J. C., Prieels, J. P., Rearick, J. I., AND HIL, R. L. (1982) in Methods in Enzymology (Ginsburg, V., Ed.), Vol. 83, pp. 458514, Academic Press, New York.

6. Eliges, M. J., AND GoldsteIn, I. J. (1985) Glyco- 
conjugates: Proceedings of the VIIIth International Symposium, Vol. 1, p. 203.

7. Plessas, N. R., Blake, D. A., and Goldstein, I. J. (1984) Carbohydr. Res. 129, 143-147.

8. Distler, J. J., AND Jourdian, G. W. (1973) J. Biol. Chem. 248, 6772-6780.

9. KilberG, M. S., AND Christensen, H. N. (1979) Biochemistry 18, 1525-1530.

10. Jansson, P., KENNE, L., LIEDGRen, H., LINDBERG, B., AND LoNngren, J. (1976) Chem. Commun. 8 , 1-76.

11. Beyer, T. A., SAdLer, J. E., AND HILL, R. L. (1980) J. Biol Chem. 255, 5364-5372.

12. Weinstein, J., De Souza-e-Silva, U., and PaUlSON, J. C. (1982) J. Biol Chem. 257, 13835-13844.

13. Schaffner, W., AND Weissmann, C. (1973) Anal. Biochem. 56, 502-514.

14. Dubois, M., Gilles, K. A., Hamilton, J. K., REBers, P. A., AND Smith, F. (1956) Anal Chem. 28, 350-356.

15. Powell, J. T., AND Brew, K. (1976) J. Biol Chem. 251, 3645-3652.

16. Brew, K., Vanaman, T. C., AND HiLL, R. L. (1968) Proc. Natl. Acad. Sci. USA 59, 491-497.

17. BABAD, H., AND HASSID, W. Z. (1966) J. Biol Chem. 241, 2672-2678.
18. ECKHARDT, A. E., AND GoldSTEIN, I. J. (1983) Biochemistry 22, 5280-5289.

19. Elices, M. J., Blake, D. A., AND Goldstein, I. J. (1986) J. Biol. Chem. 261, 6064-6072.

20. EckHARDT, A. E., AND GoldSTEIN, I. J. (1983) Biochemistry 22, 5290-5297.

21. Piller, F., Cartron, J. P., Maranduba, A., VeyRIERES, A., LEROY, Y., AND FOURNET, B. (1984) J. Biol Chem. 259, 13385-13390.

22. HaKomori, S. (1964) J. Biochem. 55, 205-208.

23. CaCCAM, J. F., AND EYlaR, E. H. (1970) Arch. Biochem. Biophys. 137, 315-324.

24. VAN DEN EIJNDEN, D. H., WINTERWERP, H., SMEEMAN, P., AND SCHIPHORST, W. E. C. M. (1983) J. Biol Chem. 258, 3435-3437.

25. Yates, A. D., AND Watkins, W. M. (1983) Carbohydr, Res. 120, 251-268.

26. Piller, F., and Cartron, J. P. (1983) J. Biol Chem. 258, 12293-12299.

27. BASU, M., AND BASU, S. (1984) J. Biol Chem. 259, 12557-12562.

28. Yamashita, K., Tachibana, Y., OHKURA, T., AND Koвata, A. (1985) J. Biol Chem. 260, 3963-3969.

29. Watanabe, K., Hakomori, S., Childs, R. A., AND FEIZI, T. (1979) J. Biol. Chem. 254, 3221-3228. 